\title{
Studi tingkat pengetahuan mengenai vitamin D pada pengemudi becak di Surabaya
}

\author{
Rivan Virlando Suryadinata ${ }^{1}$, Amelia Lorensia ${ }^{2}$, Dwi Wahyuningtyas ${ }^{2}$ \\ ${ }^{1}$ Fakultas Kedokteran, Universitas Surabaya, Surabaya \\ ${ }^{2}$ Fakultas Farmasi, Universitas Surabaya, Surabaya
}

\begin{abstract}
ABSTRAK
Kekurangan vitamin D dalam tubuh sering dihubungkan dengan berbagai macam penyakit terutama terhadap penyakitpernapasan. Hal tersebut dapat diperburuk dengan kondisipolusi udaradanmerokok. Selain itu, tingkat Pendidikan dan perubahan pola gaya hidup dimasyarakat seperti carapengolahan makanan, konsumsi, kurangnya aktivitas fisik dan lingkungan social semakin memperberat resiko kekurangan vitamin D. Salah satu mata pencaharianyang beresiko mengalami kekurangan vitamin D adalah pengemudi becak. Pengetahuan akan pentingnya peranan vitamin D pada kelompok beresiko dibutuhkan untuk dapat meningkatkan kesadaran, sehing ga dapat memberikan pencegahan secara mandiri. Pencegahan secara mandiridapat terlaksana dengan baik, apabila masyarakatmemiliki pemahana dan pengetahuan yang benar terhadap vitamin D. Tujuan penelitian ini adalah untuk mengetahuitingkatpengetahuan akan pentingnya vitamin D pada pengemudi becak di Surabaya. Penelitian ini merupakan penelitian observational dengan metode cross sectional melalui pingisian kuisiner pengetahuan viyamin D. Hasil penelitian yang telah diperoleh akan dijabarkan secara deskriptif untuk melihat gambaran pengetahuan pengemudi becak di Surabaya. Teknik sampling pada penelitian ini menggunakan purposive sampling. Sampel yang digunakan sebanyak 150 orang pengemudi becak di Surabaya. Hasil penelitian memperlihatkan bahwa pengemudibecak memiliki tingkat pengetahuan yang rendah terhadap pengetahuan akan pentingnya vitamin D terhadap kesehatan. simpulan berbagai macam faktor dapat mempengaruhi tingkat pengetahuan vitamin D terhadap pengemudi becak, sehingga dibutuhkan intervensi yang yang tepat.
\end{abstract}

Kata kunci: pengetahuan; vitamin D; pengemudi becak

\begin{abstract}
Introduction: Lack of vitamin D in the body is often associated with various diseases, especially against respiratory diseases. This can be exacerbated by conditions of air pollution and smoking. In addition, thelevelofeducation and changes in lifestyle patterns in the community such as food processing, consumption, lack of physical activity and social environment further ag gravate the risk of vitamin D deficiency. One of the livelihoods at risk of experiencing vitamin D deficiency is a pedicab driver. Knowledge of the importance of the role of vitamin D in risk groups is needed to increase awareness, provide prevention independently. Prevention can be carried out independently, if the community has the correct understanding and knowledge of vitamin D. Aim of the study: The purpose of this study is to determine the level ofknowledge of the importance of vitamin D in pedicap drivers in Surabaya. Method: This research is an observational study with cross sectional method through the filling of the vitamin D. knowledge questionnaire. Results and Discussions: The results of the research that have been obtained will be described descriptively to see the description of the knowledge of pedicap drivers in Surabaya. The sampling technique in this study used purposive sampling. The sample used was 150 pedicap drivers in Surabaya. The results showed that pedicab drivers have a low level of knowledge about the importance of vitamin D to health. Conclusion: Conclusions of various factors can influence the level of vitamin D knowledge ofpedicab drivers, so that the right intervention is needed.
\end{abstract}

Keywords: knowledge; vitamin D; pedicap drivers

* Kores pondensi penulis:

Nama : Rivan Virlando Suryadinata

Instansi: Fakultas Kedokteran, Universitas Surabaya (UBAYA)

Alamat : Jl. Tenggilis Mejoyo, Kali Rungkut, Kec. Rungkut, Kota SBY, Jawa Timur 60293/+6-231-2981000.

Email : rivan.virlando.s@staff.ubaya.ac.id. 


\section{Pendahuluan}

Kondisi kekurangan vitamin D hamper mempengaruhi separuh populasi didunia, diperkirakan hampir semua etnis dan kelompok umur mengalami kekurangan vitamin $\mathrm{D}$. Berbagai macam faktor diduga menjadi penyebab terjadinya kekurangan vitamin $\mathrm{D}$ seperti gaya hidup dan kondisi lingkungan. ${ }^{1}$ Tingginya prevalensi kekurangan vitamin D telah menjadi masalah kesehatan masyarakat yang sangat penting dikarenakan pada kondisi hipovitaminosis akan beresiko timbulnya berbagai penyakit. Berbagai penelitian memperlihatkan peranan vitamin D terhadap penyakit pernapasan, penyakit jantung, diabetes dan autoimun. Banyak pelayanan kesehata di beberapa negara telah memberikan rekomendasi pemberian suplementasi vitamin $\mathrm{D}$ hingga mencapai dosis 1000 IU. Asupan suplemen vitamin $\mathrm{D}$ telah dikaitkan secara signifikan dengan penurunan angka kematian. ${ }^{2}$

Vitamin D merupakan jenis vitamin yang sangat unik karena dapat diproduksi di kulit melalui paparan sinar matahari. Vitamin D terbagi dalam 2 bentuk yaitu vitamin D2 (ergokalsiferol) dan vitamin D3 (Cholecalsiferol). ${ }^{3}$ Vitamin D2 bersumber dari radiasi UV pada ergosterol yang merupakan bentukan steroid yang terletak di beberapa tanaman, namun didominasi oleh jamur. Sedangkan Vitamin D3 atau Cholecalsiferol disintesis melalui radiasi UV dari \&dehidrocalciferol menjadi previtamin D3 pada kulit hewan dengan Panjang gelombang UVB 290-320nm untuk membentuk vitamin D3. ${ }^{4}$ Oleh karena itu sumber vitamin D pada manusia dapat diperoleh dari berbagai sumber seperti paparan sinar matahari, asupan makanan yang bayak mengandung vitamin D3 (kuning telur dan minyak ikan), makanan yang telah difortifikasi (margarin) dan sereal (fortifikasi Vitamin D2) serata suplemen vitamin (Vitamin D2 dan D3). ${ }^{5}$

Vitamin D2 dan D3 berfungsi sebagai prohormon karena tidak memiliki efek biologis. Semua jenis Vitamin D (D2 dan D3) yang berasal dari kulit dan diet akan menjalani dua hidroksilasi secara berurutan yaitu pertama di hati $(25[\mathrm{OH}] \mathrm{D})$ dan kemudian di ginjal yang mengarah ke bentuk biologis aktifnya 1,25dihidroksivitamin $\mathrm{D}(1,25[\mathrm{OH}] 2 \mathrm{D}) .{ }^{6}$ Selanjutnya 1,25 $[\mathrm{OH}] 2 \mathrm{D}$ akan berikatan dengan reseptor vitamin D (VDR), yang dapat meningkatkan penyerapan kalsium dan fosfor usus. ${ }^{7}$ Vitamin D juga aktif terlibat dalam pembentukan tulang, resorpsi, mineralisasi, dan pemeliharaan fungsi neuromuskular. Selain itu, $1,25[\mathrm{OH}] 2 \mathrm{D}$ juga dapat menghambat tingkat serum paratiroid hormon (PTH) dengan mekanisme umpan balik negatif dan dengan peningkatan kadar kalsium serum. Hal ini mengakibatkan terjadinya pengaturan metabolisme tulang melalui aktivasi VDR pada osteoblast dan pembentukan osteoklas dewasa.

Pada keadaan vitamin D yang rendah, usus kecil hanya dapat menyerap sekitar 10\% 15\% kalsium pada makanan. Sedangkan pada keadaan normal, penyerapan kalsium makanan akan meningkat hingga sekitar 30\%-40\%. Oleh karena itu, kadar vitamin D yang rendah (25 $[\mathrm{OH}]$ D) dapat menyebabkan penyerapan kalsium yang tidak memadai sehingga memiliki implikasi klinis tidak hanya untuk kesehatan tulang tetapi juga untuk sebagian besar fungsi metabolism. ${ }^{8}$ Status vitamin D yang rendah akan menyebabkan sistem tubuh tidak dapat bekerja secara optimal, sehingga akan memicu terjadinya berbagai macam penyakit. Berbagai macam penyakit dapat ditimbulkan akibat kekurangan vitamin $\mathrm{D}$ seperti penyakit cardiovascular, diabetes, gagal ginjal kronis dan asma. ${ }^{9}$ Selain itu, vitamin $\mathrm{D}$ juga dapat digolongkan sebagai antioksidan yang berfungsi mencegah kerusakan membran sel akibat stres oksidatif. ${ }^{10}$ Hal ini dapat terjadi akibat ketidakseimbangan radikal bebas yang masuk kedalam tubuh, sehingga memicu terjadinya peroksidasi lipid. Dampak yang ditimbulkan adalah terjadinya kerusakan hingga kematian sel, sehingga meningkatkan respon inflamasi dalam tubuh. ${ }^{11,12}$

Berbagai faktor resiko dapat menyebabkan kekurangan vitamin $\mathrm{D}$ di masyarakat. Secara umum dapat dibagi dua 
bagian besar yaitu defisiensi terkait UVB dan defisiensi terkait medis/fisik. Kekurangan vitamin D terkait UVB dapat dikarenakan faktor usia karena penurunan kandugan 7dehidrokolesterol untuk sintesis vitamin D yang dimediasi paparan UVB, kurangnya aktivitas fisik, penurunan produksi ginjal 1,25 dihydroxyvitamin D serta penurunan asupan makanan. ${ }^{13}$ Selain itu, warna kulit yang gelap, kondisi cuaca dan musim serta penggunaan tabir surya juda dapat menjadi penyebab kurangnya paparan sinar matahari. Sedangkan pada kondisi medis ditemukan pada malabsorpsi lemak, penggunaan anti-konvulsan, gagal ginjal kronis dan obesitas. ${ }^{14}$

Peranan vitamin D yang sangat penting bagi kesehatan dalam mencegah timbulnya berbagai penyakit. Hal ini memberikan alasan bagi peneliti untuk mengetahui tingkat pengetahuan pada orang yang beresiko terkena kekurangan vitamin D dan salah satunya adalah pengemudi becak. Perkerjaan ini dapat dikategorikan beresiko karena para pengemudi becak selalu mendapat paparan polusi dan terlebih lagi sebagian besar adalah perokok aktif. $^{15}$ Oleh karena itu diharapkan pada penelitian ini dapat mengetahui seberapa besar tingkat pengetahuan pengemudi becak, sehingga dapat memberikan gambaran secara tepat.

\section{Metodologi}

Penelitian ini merupakan penelitian observational dengan metode cross sectional. Populasi pada penelitian ini adalah pengemudi becak di Surabaya. Kelompok penelitian yang memenuhi kriteria inklusi akan diambil sebagai sampel penelitian yaitu berjenis kelamin lakilaki, usia 25-60 tahun, tingkat Pendidikan minimal SMA. Sedangkan kriteria eksklusi dilakukan apabila kuisioner yang telah diisi tidak dapat ditelaah oleh peneliti. Besar sampel yang digunakan pada penelitian berjumlah 150 orang dengan derajat kemaknaan $5 \%$ dan kekuatan uji 95\%. Pengambilan sampel yang digunakan adalah non random sampling dengan teknik purposive sampling.
Responden pengemudi becak yang telah diwaw ancara dan sesuai dengan kriteria inklusi akan diberikan inform consent atau lembar persetujuan untuk ikut dalam penelitian dengan memberikan kuisioner mengenai tingkat pengetahuan vitamin D. Kuisioner tingkat pengetahuan vitamin $\mathrm{D}$ telah dilakukan uji validitas dan uji reliabilitas pada 30 responden yang homogen dengan responden penelitian. Uji validitas dilakukan berdasarkan pada nilai $r$ hitung (Corrected Item-Total Correlation) $>\mathrm{r}$ tabel. $\mathrm{r}$ tabel didapatkan dari tabel product moment dengan taraf signifikan 5\%, jika nilai $\mathrm{r}$ hitung > 0,361 maka pertanyaan tersebut dinyatakan valid. Sedangkan pada uji reliabilitas menggunakan korelasi Cronbach Alfa. Nilai Cronbach Alfa dikatakan reliabel apabila nilai uji reliabilitas kuisioner sama dengan atau lebih dari 0,6 .

Kuisioner yang telah diisi oleh responden akan dilakukan penilaian dan dilakukan pengkategorian yaitu pengetahuan baik dan buruk, Responden masuk kedalam kategori tingkat pengetahuan baik apabila nilai yang diperoleh lebih dari atau sama dengan 6 soal, sedangkan bila jawaban benar dibawah 6 maka diketegorikan sebagai pengetahuan buruk.

\section{Hasil dan Pembahasan}

Kuesioner digunakan dalam penelitian ini, terlebih dahulu dilakukan uji validasi. Uji ini bertujuan agar instrumen tersebut nantinya benar-benar dapat mengukur sesuatu yang hendak diteliti dan dapat melakukannya dengan cermat. Validasi dilakukan dengan memeriksa setiap item pertanyaan agar nantinya pertanyaan tersebut relevan dan benar-benar dapat mengukur aspek yang diinginkan. Kemudian kuisioner di validasi secara face (isi) dengan cara diisi oleh 30 pengemudi becak yang aktif di Surabaya. Data yang didapatkan dari kuisioner kemudian dilakukan analisis dengan program software SPSS for windows versi 24. Hasil uji validitas kuesioner pengetahuan vitamin D dipaparkan pada tabel 1 . 
Tabel 1. Hasil Uji Validasi Kuisioner Pengetahuan

\begin{tabular}{|c|c|c|c|}
\hline Pertanyaan & $\begin{array}{c}\mathbf{r} \\
\text { hitung }\end{array}$ & $\begin{array}{c}r \\
\text { tabel }\end{array}$ & Kesimpulan \\
\hline $\begin{array}{l}\text { Apakah anda pernah } \\
\text { mengetahui tentang vitamin D? } \\
\text { Apa itu vitamin D? }\end{array}$ & 0,570 & 0,361 & Valid \\
\hline $\begin{array}{l}\text { Dari mana anda mengetahui } \\
\text { tentang vitamin } D \text { ? }\end{array}$ & 0,659 & 0,361 & Valid \\
\hline $\begin{array}{l}\text { Apa sumber terbesar vitamin } \\
\text { D? }\end{array}$ & & & \\
\hline $\begin{array}{l}\text { Selain sumber terbesar, } \\
\text { sebutkan sumber lain dari } \\
\text { vitamin D! }\end{array}$ & 0,439 & 0,361 & Valid \\
\hline $\begin{array}{l}\text { Apa manfaat vitamin D bagi } \\
\text { tubuh? }\end{array}$ & 0,408 & 0,361 & Valid \\
\hline $\begin{array}{l}\text { Apakah akibat dari kekurangan } \\
\text { vitamin D? }\end{array}$ & 0,441 & 0,361 & Valid \\
\hline $\begin{array}{l}\text { Berikut ini, manakah yang } \\
\text { dapat menyebabkan tubuh } \\
\text { anda kekurangan vitamin D? }\end{array}$ & 0,702 & 0,361 & Valid \\
\hline $\begin{array}{l}\text { Menurut anda, apakah sinar } \\
\text { matahari dapat membantu } \\
\text { menghasilkan vitamin D? } \\
\text { Alasannya }\end{array}$ & 0,647 & 0,361 & Valid \\
\hline $\begin{array}{l}\text { Apakah sinar matahari } \\
\text { berbahaya bagi kulit? } \\
\text { Alasannya }\end{array}$ & 0,428 & 0,361 & Valid \\
\hline $\begin{array}{l}\text { Menurut anda, waktu yang } \\
\text { baik untuk terkena paparan } \\
\text { sinar matahari secara langsung } \\
\text { yaitu dari jam ... sampai } \\
\text { dengan jam .... agar tubuh } \\
\text { memperoleh vitamin D }\end{array}$ & 0,445 & 0,361 & Valid \\
\hline $\begin{array}{l}\text { Berapa lama waktu yang } \\
\text { diperlukan oleh tubuh untuk } \\
\text { terpapar sinar matahari secara } \\
\text { langsung agar memperoleh } \\
\text { vitamin D? }\end{array}$ & 0,381 & 0,361 & Valid \\
\hline $\begin{array}{l}\text { Berapakah jumlah SPF (Sun } \\
\text { Protection Factor) yang baik } \\
\text { bagi tubuh anda? }\end{array}$ & 0,528 & 0,361 & Valid \\
\hline
\end{tabular}

Hasil uji validitas tabel 1. kuesioner pengetahuan terhadap paparan sinar matahari dinyatakan valid. Kuesioner dapat dikatakan valid jika ( $\mathrm{r}$ hitung > $\mathrm{r}$ tabel product moment), dimana nilai $\mathrm{r}$ tabel untuk 30 responden 0,361 dan semua item pertanyaan dari kuesioner tersebut memiliki nilai di atas nilai $r$ tabel product moment. Hasil uji reliabilitas tabel 2. kuesioner pengetahuan terhadap vitamin D dinyatakan reliabel karena memiliki nilai Cronbach Alpha 0,660.

Tabel 2. Hasil Uji Reliabilitas Kuisioner Pengetahuan Reliability Statistic

\begin{tabular}{cc}
\hline \multicolumn{2}{c}{ Reliability Statis tic } \\
\hline Jumlah Pertanyaan & Cronbach's Alpha \\
11 & 0,660 \\
\hline
\end{tabular}

Hasil penilaian kuisioner tingkat pengetahuan pada pengemudi becak dikategorikan menjadi pengetahuan baik dan buruk. Berdasarkan tabel 3. memperlihatkan pengemudi becak yang memiliki pengetahuan baik terhadap vitamin D sebesar 7,3\% sedangkan yang memiliki pengetahuan buruk mencapai $92,7 \%$.

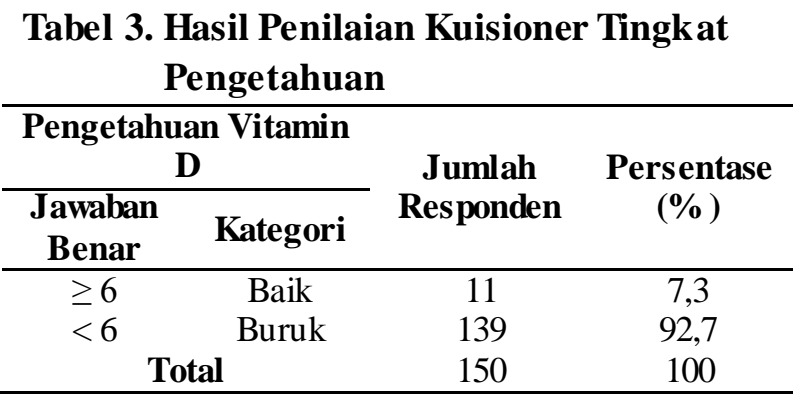

Vitamin D berperan penting dalam pemeliharaan fisiologi dan kesehatan. Namun, sebagian besar responden masih belum menyadari tentang pentingnya vitamin $\mathrm{D}$ terhadap implikasi kesehatan pada dirinya. Beberapa penelitian terkait dengan teori survei pengetahuan, sikap dan praktik seseorang menunjukkan hubungan yang linier secara langsung antara pengetahuan, sikap dan perilaku seseorang. Namun demikian, perilaku seseorang juga memiliki multifaktorial dan bergantung pada banyak faktor seperti pendidikan, pola asuh, sosial budaya dan lingkungan. ${ }^{16,17}$ Oleh karena itu, pendidikan publik mengenai pentingnya vitamin D dibutuhkan di masyarakat, sehingga diharapkan kesadaran tersebut dapat mengarah kepada tindakan seseorang yang berpotensi menigkatkan kadar vitamin D melalui makanan dan perubahan pola hidup. ${ }^{18}$

Vitamin D berfungsi aktif pada semua sistem organ, termasuk organ tubuh yang berperan dalam kebugaran, seperti otot, jantung dan pernapasan. Di dalam sel tubuh, vitamin D memiliki fungsi saat kontraksi otot, meningkatkan kekuatan otot, massa otot dan volume. Hasil studi sebelumnya juga menyebutkan bahwa aktifitas fisik seperti yoga, yang dalam ini merupakan bentuk latihan fisik 
intensitas sedang dapat meningkatkan kebugaran fisik dan status kesehatan. ${ }^{19}$

Paparan sinar matahari yang diperoleh saat individu beraktivitas di luar dalam jumlah yang tepat dianggap sangat penting untuk meningkatkan kadar vitamin D dalam tubuh. Masyarakat perlu mengetahui manfaat saat beraktivitas fisik dan konsumsi makanan yang mengandung vitamin D. Karena minimnya pengetahuan tentang manfaat vitamin D akan memengaruhi sikap dan pemilihan jenis makanan. ${ }^{17}$

Pada studi terdahulu diperoleh data tentang pengetahuan masyarakat tentang tiga sumber vitamin D utama yaitu sinar matahari, makanan, dan suplemen. Persentase terbesar responden mengidentifikasi sumber vitamin D adalah matahari (99\%), suplemen $(87 \%)$ dan makanan $(84 \%)$. Namun, masyarakat memiliki pengetahuan yang kurang tentang sumber vitamin D yang berasal dari makanan. Sebagian besar masyarakat menganggap produk susu dan sayuran sebagai sumber vitamin D. Responden dalam penelitian ini memiliki pengetahuan yang cukup baik tentang efek sinar matahari dan berbagai faktor yang memengaruhi sintesis vitamin D. Studi kami menunjukkan bahwa lebih dari setengah (56\%) dari populasi memiliki sikap positif terhadap paparan sinar matahari, karena mereka biasanya mencari sinar matahari langsung, kadang-kadang memakai tabir surya atau berenc ana untuk paparan / penyamakan dan menghabiskan 12,2 $\pm 8,6$ siang hari rata-rata jam per minggu di luar rumah, sebagian besar saat sore hari. ${ }^{20}$ Hal ini menjadi penting bahwa perlunya pengetahuan individu tentang sumber vitamin D yang berasal dari sinar matahari dan makanan sehingga dapat mencapai status kesehatan yang lebih optimal.

\section{Kesimpulan}

Pengemudi becak memiliki tingkat pengetahuan yang kurang mengenai pentingnya vitamin D terhadap kesehatan, sehingga dibutuhkan pendidikan publik yang sesuai dan tepat.

\section{Ucapan Terima Kasih}

Peneliti berterima kasih kepada seluruh responden yang telah berpartisipasi dalam penelitian ini.

\section{Referensi}

1. Gani L, How C. Vitamin D deficiency. Singapore Med J [Internet]. 2015 Aug [cited 2020 Jun 1];56(08):433-7. Available from: http://www.smj.org.sg/artic le/vitamin-ddeficiency.

2. Nair R, Maseeh A. Vitamin D: The "sunshine" vitamin. J Pharmacol Pharmacother [Internet]. 2012 Apr [cited 2020 Jun 1];3(2):118-26. Available from: http://www.ncbi.nlm.nih.gov/pubmed/22629 085.

3. Suryadinata RV, Lorensia A, Aprilia AP. Profil Vitamin D Pada Pasien Asma dan Non-Asma Dewasa di Surabaya. Indones J Public Heal [Internet]. 2017 Dec 28 [cited 2020 Jun 1];12(1):106. Available from: https://ejournal.unair.ac.id/IJPH/article/view/7175.

4. Hammami MM, Yusuf A. Differential effects of vitamin D2 and D3 supplements on 25-hydroxyvitamin D level are dose, sex, and time dependent: a randomized controlled trial. BMC Endocr Disord [Internet]. 2017 Dec 24 [cited 2020 Jun 1];17(1):12. Available from: http://bmcendocrdisord.biomedcentral.com/ articles/10.1186/s12902-017-0163-9.

5. Tripkovic L, Lambert H, Hart K, Smith CP, Bucca G, Penson S, et al. Comparison of vitamin D2 and vitamin D3 supplementation in raising serum 25-hydroxyvitamin D status: a systematic review and metaanalysis. Am J Clin Nutr [Internet]. 2012 Jun 1 [cited 2020 Jun 1];95(6):1357-64. Available

from: https://academic.oup.com/ajcn/article/95/6/1 357/4568382.

6. Biancuzzo RM, Young A, Bibuld D, Cai $\mathrm{MH}$, Winter MR, Klein EK, et al. Fortification of orange juice with vitamin $\mathrm{D}(2)$ or vitamin $\mathrm{D}(3)$ is as effective as an 
oral supplement in maintaining vitamin D status in adults. Am J Clin Nutr [Internet]. 2010 Jun [cited 2020 Jun 1];91(6):1621-6. Available from: http://www.ncbi.nlm.nih.gov/pubmed/20427 729.

7. Hollis BW, Wagner CL. Clinical review: The role of the parent compound vitamin D with respect to metabolism and function: Why clinical dose intervals can affect clinical outcomes. J Clin Endocrinol Metab [Internet]. 2013 Dec [cited 2020 Jun 1];98(12):4619-28. Available from: http://ww w.ncbi.nlm.nih.gov/pubmed/24106 283.

8. Suryadinata RV, Wirjatmadi B, Adriani M, Sumarmi S. Effects of knowledge of vitamin D on attitudes tow ard sun exposure among middle-aged and elderly Indonesian adults. Indian J Public Heal Res Dev. [Internet]. 2018 [cited 2020 Jun 1];9(11):1692-1696. Available from: http://dx.doi.org/10.5958/09765506.2018.01686.8.

9. Lorensia A, Suryadinata RV, Saputra R. Physical Activity and Vitamin D Level in Asthma and Non-Asthma. JFIOnline | Print ISSN 1412-1107 | e-ISSN 2355-696X [Internet]. 2019 May 26 [cited 2020 Jun 1];11(1). Available from: http://jfionline.org/index.php/jurnal/article/v iew/591.

10. Suryadinata RV, Lorensia A, Tangkilisan EC. Effect of Physical Activity and Vitamin D Status on Geriatrics Obesity. Glob Med Heal Commun. [Internet]. 2019 [cited 2020 Jun 1];7(1):1-6. Available from: https://ejournal.unisba.ac.id/index.php/gmhc /article/view/2916.

11. Suryadinata RV, Wirjatmadi B, Adriani M. Efektivitas Penurunan Malondialdehyde dengan Kombinasi Suplemen Antioksidan Superoxide Dismutase Melon dan Gliadin Akibat Paparan Rokok. Glob Med Helath Commun [Internet]. 2017 [cited 2020 Jun 1];5(2):79-83. Available from: https://ejournal.unisba.ac.id/index.php/gmhe /article/view/1860.

12. Lorensia A, Suryadinata RV, Amir GA. Relation between Vitamin D Level and Knowledge and Attitude Tow ards Sunlight Exposure among Asthma Outpatients in Surabaya. Glob Med Heal Commun. [Internet]. 2019 [cited 2020 Jun 1];7(3):162-9. Available from: https://ejournal.unisba.ac.id/index.php/gmhe /article/view/3094.

13. Suryadinata RV, Sukarno DA. The Effect of Physical Activity on The Risk of Obesity in Adulthood. Indones J Public Heal [Internet]. 2019 Jul 5 [cited 2020 Jun 1];14(1):104. Available from: https://ejournal.unair.ac.id/IJPH/article/view/7509.

14. Zhang R, Naughton DP. Vitamin D in health and disease: Current perspectives. Nutr $\mathrm{J}$ [Internet]. 2010 Dec 8 [cited 2020 Jun 1];9(1):65. Available from: http://nutritionj.biomedcentral.com/articles/ 10.1186/1475-2891-9-65.

15. Lorensia A, Suryadinata RV, Diputra INY. Risk Factors and Early Symptoms Related to Respiratory Disease in Pedicab Drivers in Surabaya. J Kesehat Masy [Internet]. 2019 Dec 22 [cited 2020 Jun 1];15(2):223-34. Available from: https://journal.unnes.ac.id/nju/index.php/ke mas/article/view/19255.

16. Aljefree NM, Lee P, Ahmed F. Knowledge and attitudes about vitamin $\mathrm{D}$, and behaviors related to vitamin $\mathrm{D}$ in adults with and without coronary heart disease in Saudi Arabia. BMC Public Health [Internet]. 2017 Dec 16 [cited 2020 Jun 1];17(1):266. Available from: http://bmcpublichealth.biomedcentral.com/a rticles/10.1186/s12889-017-4183-1.

17. Suryadinata RV, Lorensia A. Food Frequency, Knowledge about Vitamin D and Obesity among Elderly. Amerta Nutr. [Internet]. 2020 [cited 2020 Jun 1];4(1):438.

18. Alshamsan F, Bin-Abbas B. Knowledge, aw areness, attitudes and sources of vitamin $D$ deficiency and sufficiency in Saudi 
children. Saudi Med J [Internet]. 2016 May 1 [cited 2020 Jun 1];37(5):579-83. Available from: http://www.smj.org.sa/index.php/smj/article/ view/smj.2016.5.14951.

19. Wibowo SW. Model Aktivitas Dengan Paparan Sinar Matahari Untuk Meningkatkan Tingkat Kebugaran Pada Anak Dengan Hambatan Visual. Jurnal Asesmen dan Intervensi Anak Berkebutuhan Khusus [Internet]. 2016 May 1 [cited 2020 Jun 1];37(5):579-83. Available from: https://ejournal.upi.edu/index.php/jassi/articl e/view/15442.

20. O'Connor C, Glatt D, White L, Revuelta Iniesta R. Knowledge, Attitudes and Perceptions towards Vitamin D in a UK Adult Population: A Cross-Sectional Study. Int J Environ Res Public Health [Internet]. 2018 Oct 27 [cited 2020 Jun 1];15(11):2387. Available from: https://doi.org/10.3390/ijerph15112387. 